\title{
Pesantren dan Multikulturalisme di Madura: Adaptasi Nilai Multikultural dalam Menciptakan Kenukunan Masyarakat Multi Etnis dan Agama
}

\author{
Mo'tasim $^{\text {a) }}$, Maskuri Bakrib), Djunaidi Mistar ${ }^{\text {c) }}$, M. Djunaidi Ghony ${ }^{\mathrm{d})}$, Nia Indah Purnamasarie) \\ a) STIT Al Ibrohimy Bangkalan \\ b) Universitas Islam Malang \\ c) Universitas Islam Malang \\ d) Universitas Islam Malang \\ e) STAI YPBWI Surabaya
}

\section{ABSTRAK}

Kerukunan masyarakat multi etnis dan agama di satu daerah selalu menarik untuk dibahas, karena dapat memberikan solusi kepada daerah sejenis yang masih berkonflik. Penelitian ini bertujuan untuk menganalisis proses adaptasi nilai-nilai multikultural yang dilakukan Pesantren Miftahul Qulub dalam menciptakan kerukunan masyarakat multi etnis dan agama di desa Polagan Pamekasan Madura. Penelitian fenomenologis ini menemukan bahwa proses adaptasi nilai multikultural dilakukan melalui pendekatan tradisi kemasyarakatan, mazhab moderat, dakwah, dan modal sosial. Beberapa pendekatan tersebut merupakan aktualisasi dari pembudayaan nilai keislaman dan jiwa Nahdhatu Ulama (NU), sehingga membuat pesantren begitu mudah diterima dan membaur dengan masyarakat multikultur. Dilihat dari kaca mata pedagogis, pesantren Miftahul Qulub menekankan proses pembelajaran berbasis masyarakat. Oleh sebab itu, konsep tersebut dapat menjadi refleksi bagi lembaga lain adalah kurikulum dan budaya akademik harus diadaptasi dengan kebutuhan masyarakat yang beragam, dinamis dan berkembang.

\section{ABSTRACT}

The harmony of multi-ethnic and religious communities in an area is always interesting to discuss because it can provide solutions to conflict-affected areas. This phenomenological study aims to analyze the adaptation process of multicultural values carried out by Pesantren Miftahul Qulub in building social harmony in multi-ethnic and religious village of Polagan, Pamekasan, Madura. This phenomenological research demonstrates that multicultural adaptation goes through local culture, moderate school of thoughts, outreach, and social capital. Some of these approaches are the actualization and dissemination of Islamic values and Nahdhatul Ulama (NU) spirit that makes pesantren so easily accepted and mingles within multicultural communities. Seen from a pedagogical perspective, Pesantren Miftahul Qulub emphasizes the community-based learning process. Therefore, this concept can be a reflection for other pesantren, that the curriculum and academic culture must be adapted to the needs of a diverse, dynamic and developing society.
KATA KUNCI

Pesantren; Multikulturalisme; Masyarakat Multi Etnis dan Agama; Toleransi

\section{A. Pendahuluan}

Madura kerap diidentikkan dengan stereotype keras, kasar dan garang yang menjurus singgungan fisik yang dikenal dengan "carok." ${ }^{1}$ Bahkan, De Jonge, mendeskripsikan Madura dalam perspektif antropologis dengan segala menifestasi sosial-budayanya rentan akan ketegangan dan

\footnotetext{
${ }^{1}$ Baca, Latief Wiyata, Carok: Konflik Kekerasan dan Harga Diri Orang Madura (Yogyakarta: Lkis, 2002). CONTACT Mo'tasim Dbillahmutasim73@yahoo.com $\square$ STIT Al-lbrohimy, Jl. Raya Galis No. 03, Kec. Galis, Kab. Bangkalan, Jawa 
Mo’tasim, Maskuri Bakri, Djunaidi Mistar, M. Djunaidy Ghony, Nia Indah Purnamasari

kekerasan. ${ }^{2}$ Namun, argumen tersebut terpatahkan ketika melihat lebih dalam pulau garam. Dengan segala label negatif yang melekat, sebuah daerah di Pamekasan Madura justru menggambarkan masyarakat yang rukun dan harmonis. Desa Polagan yang merupakan desa kecil di Pamekasan Madura ini didaulat menjadi ikon kerukunan. Dalam penelitian Ketal, kerukunan masyarakat yang multi etnis dan agama tersimbolisasi dengan bangunan vihara yang megah. ${ }^{3}$

Ditinjau dari segi etnisitas, masyarakat desa Pologan terdiri dari etnis Madura, dan Tionghoa.Dari jumlah penduduk yang menurut data desa berjumlah 5578 dengan 1793 kartu keluarga (KK). Kemudian ditinjau dari aspek agama, Muslim sekitar 75\%, Budha 10\%, Hindu 10\%, dan Konghucu 5\%, ${ }^{4}$ yang tempat ibadahnya berada di dalam satu kompleks Vihara Avalokitasvara. ${ }^{5}$ Realitas ini pernah disebut Vihara Avalokitesvara sebagai bangunan peribadatan dari agama Budha sebagai wajah penampilan dari cita-cita masyarakat Pancasila. ${ }^{6}$

Pernyataan ini berdasar pada keberagaman bangunan atau tempat peribadatan yang ada dalam komplek Vihara ${ }^{7}$ yaitu ada empat tempat ibadah: Musalla untuk ummat Muslim, Pura untuk ummat Hindu, Lithang untuk Ummat Konghucu, Dhammasala untuk ummat Budha. Keempatnya menyatu dalam satu lokasi dan sama-sama dibangun dan berdiri megah. Namun jika dilihat dari luar nampak sekali dua bangunan pagoda kembar menjulang sebagai sebuah simbol toleransi dan kerukunan umat beragama. Keberagaman dan menjunjung tinggi nilai-nilai dan cita-cita pancasila sebagaimana telah dibangun dalam komplek vihara tersebut sebuah prasasti atau bangunan yang ditulis diatasnya butir-butir pancasila sebagai tujuan dari keberadaan sebuah komplek tempat ibadah yang multi agama.

Keberagaman etnis di desa Polagan memberikan dampak terhadap terjadinya konfigurasi sosial keagamaan dan budaya. Misalnya ketika Muslim setempat merayakan Maulid Nabi Muhammad SAW atau hari raya Idul Fitri, etnis Tionghoa juga datang dan ikut merayakan acara tersebut. Dan juga ketika etnis Tionghoa merayakan hari-hari besar seperti hari ulang tahun Dewi Kuain Inn, atau perayaan Imlek, masyarakat Muslim juga ikut datang dan bahkan tokoh setempat memberikan doa pada acara yang diselenggarakan di Vihara. ${ }^{8}$

\footnotetext{
${ }^{2}$ Huub De Jonge, Garam, Kekerasan dan Aduan Sapi; Esai-esai tentang Orang Madura dan Kebudayaan Madura, Terj. Arief B. Prasetyo (Yogyakarta: LkiS, 2011), 59-64.

${ }^{3}$ Felicia Tania Ketal, "Ikonografi Panofsky pada Ornament Interior Vihara Avalokitesvara Pamekasan Madura," Jurnal Intra, Vol.5, No. 2 (2017).

${ }^{4}$ Data ini diambil dari data survey penelitian, (yang bisa berubah) bukan data sensus yang bersifat tetap

${ }^{5}$ Monografi Desa Polagan Pamekasan Madura tahun 2019.

${ }^{6}$ SWJ, Wawancara, Pamekasan, 1 Agustus 2019

7 Vihara adalah istilah India kuno untuk biara Buddha. Awalnya, vihara adalah tempat tinggal yang digunakan oleh biksu pengembara selama musim hujan. Selanjutnya, vihara berkembang menjadi pusat pembelajaran dan arsitektur pemeluk agama Buddha. Lihat, Nurtati Soewarno, "Adaptation Of Architectural Style To Preserve Cultural Heritage Building; Case Study at Vihara Dewi Welas Asih-Cirebon", Journal of Architectural Research and Education (JARE), Vol. 2, No. 1 (2020).

${ }^{8} \mathrm{MH}$, Wawancara, Pamekasan, 14 Februari 2019.
} 
Kerukunan dalam Vihara sendiri terpola dengan diterimanya dengan hangat agama seperti Buddha dan Konghucu bahkan agama Lithang (toa) yang memang dibangun megah di kompleks Vihara. ${ }^{9}$ Kerukunan yang bertahan lama ini (selama tiga abad) sejak berdirinya Vihara Avalokitasvara juga tidak terlepas dari berbagai faktor yang akan peneliti kaji, salah satunya adalah peran Pesantren Miftahul Qulub yang berada di samping Vihara (kurang lebih $100 \mathrm{~m}$ dari Vihara). Pesantren tersebut memberikan kontribusi pendidikan kerukunan sejak dini, sebab menurut salah satu informan, anakanak etnis Tionghoa juga belajar di Madrasah ini. ${ }^{10}$ Mereka belajar bersama tanpa harus melihat perbedaan. Di Madrasah mereka juga mendapat perlakuan yang sama dalam kegiatan belajar mengajar (equity pedagogy). ${ }^{11}$

Pesantren ini telah melakukan interaksi dengan masyarakat multi etnis dan agama sejak tahun berdirinya. Selain sebagai lembaga pendidikan, Pesantren ini telah melakukan adaptasi nilai pendidikan Islam Multikultural melalui varian proses adaptasi nilai-nilai tersebut baik dalam bentuk sosial keagamaan, maupun dengan pendekatan tradisi dan budaya masyarakat. Faktor pendiri pesantren yang berlatar belakang aliran nahdliyyah (NU) menjadikan pesantren Miftahul Qulub bercirikan ke-NU-an. Hal ini tercermin dalam sistem pembelajaran dengan penguasaan kitab kuning sebagai tradisi keilmuan. Pesantren yang menjaga tradisi masyarakat sekitar yang juga merupakan masyarakat NU pada umumnya. Sehingga pesantren ini mendapat dukungan baik dari masyarakat. Relasi dan hubungan pesantren denga masyarakat sangat erat bahkan pesantren selain menjadi pusat pendidikan santri juga menjadi pusat kegiatan pengajian masyarakat sekitar. ${ }^{12}$

Pesantren Miftahul Qulub lebih mengedepankan nilai kemanusiaan dalam proses pendidikannya. Hal ini disebutkan Supandi bahwa pesantren ini mengimplementasikan pembelajaran akhlak dalam perspektif kemanusiaan dengan bertujuan untuk meningkatkan potensi anak didik. Dengan demikian, pendekatan kemanusiaan ini akan memberikan dampak dan pengaruh yang positif terhadap keberhasilan pelaksanaan kegiatan pembelajaran. Kemudian pembelajaran yang humanistis merupakan implementasi pembelajaran yang memandang siswa sebagai manusia yang sama antara yang satu dengan yang lainnya, sehingga akhlakul karimah adalah dasar bagi terjalinnya komunikasi antara guru dengan siswa. Pendekatan kemanusiaan dalam pembelajaran adalah ruh yang dapat disandingkan dengan berbagai macam metode pembelajaran. Sehingga pendekatan ini dapat

\footnotetext{
${ }^{9} \mathrm{KS}$, Wawancara, Pamekasan, 14 Februari 2019.

${ }^{10} \mathrm{MH}$, Wawancara, Pamekasan, 14 Februari 2019

${ }^{11}$ Banks mendefinisikan equity pedagogy sebagai strategi pengajaran dan lingkungan kelas yang membantu siswa dari kelompok ras, etnis, dan budaya yang beragam memperoleh pengetahuan, keterampilan, dan sikap yang diperlukan untuk berfungsi secara efektif di dalam, dan menciptakan serta mengabadikan, adil, manusiawi, dan masyarakat yang demokratis. Lihat, C. A. M. Banks \& J. A Banks,. "Equity Pedagogy: An Essential Component of Multicultural Education," Theory into Practice, Vol. 34, No. 3 (1995): 151-158. Lihat pula, James A. Banks, Multicultural Education: Goals and Dimension (Washington DC: University of Washington College of Education, 2011).

${ }^{12}$ RZK, Wawancara, Pamekasan, 17 September 2019.
} 
Mo’tasim, Maskuri Bakri, Djunaidi Mistar, M. Djunaidy Ghony, Nia Indah Purnamasari

membuat para siswa belajar dengan senang dan gembira yang akhirnya akan dapat dengan mudah untuk menerima materi pelajaran. ${ }^{13}$

Adaptasi nilai pendidikan Islam multikultural yang dilakukan pesantren Miftahul Qulub menyesuaikan dan memelihara sebuah pendekatan tradisi sosial kemasyarakatan. Pesantren ini mendirikan dan membina madrasah yang berada di Polagan. Pesantren ini juga melakukan proses adaptasi lainnya melalui kegiatan keagamaan. ${ }^{14}$ Untuk mengungkap dan menganalisis realitas harmonisasi di tengah masyarakat Polagan yang multi etnis dan agama, maka penelitian ini dilakukan untuk membahas lebih dalam tentang bagaimana proses pesantren mengadaptasi kerukunan dalam masyarakat multi etnis dan agama di Desa Polagan Pamekasan, Madura, dengan mempertimbangkan teori sosial fungsionalisme struktural Talcott Parsons dan teori survivalitas Bourdieu.

\section{B. Beberapa Pendekatan dalam Menciptakan Kerukunan Masyarakat Plural}

\section{Pendekatan Tradisi Sosial Kemasyarakatan}

Dalam temuan Imam Suprayogo tentang kerukunan masyarakat multi agama di mana masyarakat membutuhkan faktor-faktor yang mendukung kerukunan hidup antar umat beragama. Pertama faktor tradisi. Di mana faktor ini telah ada sejak dulu dan masih tetap terpelihara hingga saat ini. Kedua, faktor aliran dan mazhab. Di mana faktor aliran dan mazhab yang ada di dalam agama-agama merupakan aliran dan mazhab yang moderat. Ketiga faktor dakwah dan misi. Dakwah disampaikan dengan pendekatan tokoh agama dalam menciptakan kerukunan bersifat etishumanis dan kultural. ${ }^{15}$

Pandangan Suprayogo tersebut secara simultan terkontekstualisasikan dalam kehidupan masyarakat multi agama dan etnis di Polagan. Di mana faktor tradisi toleransi telah terjadi sejak turun temurun. Tradisi saling menghoramti dalam melakukan kegiatan keagamaan maupun tradisi yang bersifat lokal kultur masyarakat seperti peringatan hari besar agama dan kegiatan rutinitas seperti "kompolan" atau tradisi tahlilan yang diikuti oleh berbagai etnis di Polagan. Pendekatan tradisi sosial kemasyarakat merupakan asas pesantren dalam melakukan salah satu skema AGIL daalam teori Person yaitu latency ${ }^{16}$ bagaimana pesantren sebagai sub sitem sosial yang mengatur norma tradisi masyarakat.

\footnotetext{
${ }^{13}$ Supandi, "Pembelajaran Aqidah Akhlak dalam Perspektif Humanisme di MA Miftahul Qulub Galis Pamekasan," Edureligia: Jurnal Pendidikan Agama Islam, Vol. 3, No. 1 (Juli - Desember 2019), 125.

${ }^{14}$ Observasi penulis di Pesantren Miftahul Qulub Pamekasan pada 3 Mei 2019.

${ }^{15}$ Imam Suprayogo, et al. Merajut Benang Kusut: Studi Kasus Kerukunan Hidup Antarumat Beragama di Sitiarjo Kecamatan Sumbermanjing Wetan Kabupaten Malang (Malang: Laporan Penelitian Hibah Bersaing Dosen lain/Stain Sekolah Tinggi Agama Islam Negeri (STAIN) Malang, 2001), 9.

${ }^{16}$ George Ritzer \& Douglas J, Teori Sosiologi Dari Teori Sosiologi Klasik Sampai Perkembangan Terakhir, Teori Sosial Post Modern (Bantul: Kreasi Wacana, 2012), 257.
} 
Telah banyak kajian yang menunjukkan peran pesantren dalam pembangunan masyarakat, atau fungsi pesantren dalam perubahan masyarakat telah terbukti dalam sejarah perjalanan pesantren di Nusantara. Mastuhu menyebutkan bahwa pesantren tidak hanya sebagai lembaga pendidikan Islam, tetapi juga sebagai lembaga penyebaran agama Islam. Pesantren adalah lembaga yang paling menentukan watak keislaman dan kerajaan Islam. Disebutkan juga bahwa pesantren pada masa kolonial yang banyak berubungan dengan masyarakat bahkan menyatu dengan kehidupan masyarakat. ${ }^{17}$

Pesantren Miftahul Qulub dalam melakukan adaptasi nilai multikulturalisme menggunakan strategi adaptasi, integrasi dan pemeliharaan sebuah pendekatan tradisi sosial kemasyarakatan. Pesantren ini mendirikan dan membina madrasah yang berada di dusun Candi, ${ }^{18}$ pesantren ini juga melakukan adaptasi lainnya seperti Kompolan Malam Jumatan, Peringatan Maulid Nabi, ikut serta mensukseskan perayaan hari besar yang diselenggarakan masarakat Tionghoa di Vihara. Pesantren juga mengadaptasi kebutuhan masyarakat Tionghoa dalam perayaan hari raya Imlek, dst.

Pesantren Miftahul Qulub melakukan adaptasi dengan pendekatan kultur, simbolik dan ekonomi. Pendekatan kultur, Pesantren ini membangun adaptasi kebutuhan pendidikan masyarakat dengan pendekatan Pendidikan Agama Islam yang bersifat ke-NU-an atau cenderung lebih membina masyarakat bawah secara telaten. Pesantren ini juga secara ekonomi telah mampu berdiri sediri dengan swasembada hasil pertanian dan ekomoni kreatif, sehingga santri yang tidak mampu tidak dikenakan biaya pendidikan. Secara simbolik pesantren Miftahul Qulub hingga saat ini menjadi lembaga pendidikan yang menjadi simbol pesantren kerukunan dan kepedulian dan harmonisasi, sebab realitas harmonisasi di tengah masyarakat Polagan yang multi etnis dan agama tidak dapat dilepaskan dari peran dan fungsi pesantren yang hadir di tengah-tengah mereka.

\section{Pendekatan Mazhab Moderat}

Pendekatan aliran atau Mazhab yang moderat menjadi faktor kedua dalam menciptakan kerukunan masyarakat. ${ }^{19}$ Tokoh Islam dan tokoh masyarakat Tionghoa di Polagan sama-sama menampilkan sosok yang moderat dalam bersikap dan saling menghargai satu dengan lainnya. Aliran masyarakat muslim yang berada di Polagan adalah masyarakat aliran Sunni Nahdlatul Ulama' (NU) sementara umat Buddha dan Hindu kemudian Konghucu juga aliran moderat sehingga keberadaan perbedaan agama di Polagan tidak menjadi masalah. Ditambah lagi keberadaan sebuah pesantren yang beraliran NU menambah dialog antar agama di Polagan terjalin dengan baik.

\footnotetext{
${ }^{17}$ Matuhu, Dinamika Sistem Pendidikan Pesantren (Jakarta: INIS, 1994), 21.

${ }^{18}$ Salah satu dusun yang masyarakat multi etnis dan agama lebih banyak dari dusun lainnya di Desa Polagan. Di dusun ini juga berdiri mega bangunan Vihara Avalokistasvara.

${ }^{19}$ Suprayogo et al., Merajut Benang Kusut, 9.
} 
Mo’tasim, Maskuri Bakri, Djunaidi Mistar, M. Djunaidy Ghony, Nia Indah Purnamasari

Pendekatan aliran ini diadaptasi oleh Pesantren Miftahul Qulub, sehingga pesantren berperan sebagai perekat umat beragama dan pemersatu masyarakat sebab pesantren melakukan proses edukasi moderasi melalui keteladanan tokohnya yaitu Kiai. Kiai sebagai pendidik dan perumus mampu merumuskan kehidupan yang moderat dengan tetap menjalankan tradisi masyarakat. Pesantren Miftahul Qulub melakukan pendekatan moderate bermakna mengambil sikap tengah: tidak berlebih-lebihan pada satu posisi tertentu. Moderat mampu menyatukan dua kubu atau lebih persoalan secara seimbang dan harmonis dengan tampa mengorbankan nilai-nilai kebenaran. Pesantren Miftahul Qulub menampilkan wajah NU yang dalam pandangan Masdar Hilmy mengedepankan tawassuth, tawazun dan i'tidal dalam formulasi gerakannya sebagai oraganisasi masyarakat dan keagamaaan. Hal ini sebagai bentuk upaya terus menurus dalam menciptakan moderasi Islam di Indonesia. Di mana menurut Hilmy praksis moderasi harus dipraksiskan dalam bentuk kerjasama hingga pada level yang paling kecil dalam lembaga di pemerintah. Sehingga prinsip moderasi tidak hanya mencerminkan nilai keislaman tapi juga menjadi cerminan nilai kebangsaaan. ${ }^{20}$

Al Zuhaily, bahkan perlu menegaskan bahwa moderasi beragama merupakan kesungguhan bersikap lunak agar tidak terjerumus ekstrimisme. la menekankan keseimbangan dalam keyakinan, sikap, perilaku, tatanan, muamalah dan moralitas. Dengan kata lain, Islam harus dijadikan sebagai agama yang mengambil jalan tengah, tidak berlebihan dalam segala perkara, termasuk agama, ideologi, sikap politik dan lain sebagainya. ${ }^{21}$ Secara historis Islam Indonesia merupakan komunitas Islam yang disebut sebagai "ummatan washatan" (ummat yang mempraktikkan Islam moderat)". Tarmizi Taher (1992-97) telah mengkampanyekan Islam Indonesia sebagai contoh aktualisasi "ummatan washatan" dalam berbagai aspek kehidupan umat Islam pada masa kontemporer. ${ }^{22}$ Dalam menggunakan istilah "wasathan" Al-Asfahaniy, cenderung mendefinisikannya dengan keadilan. ${ }^{23}$ Istilah adil Al-Asfahaniy, juga terdapat dalam Mu'jam al-Wasith, di mana sikap berada di tengah menjadi alternatif terbaik. ${ }^{24}$ Sementara, al-Jazâ'iri menafsirkan kata "ummatan wasathan" dalam Al-Qur'an sebagai umat pilihan yang adil, terbaik dan mempunyai misi meluruskan. ${ }^{25}$ Untuk mengaktualisasikan sikap moderat tersebut, Hilmy mensyaratkan karakter: toleransi, harmoni dan kerjasama antar kelompok agama yang berbeda. ${ }^{26}$ Oleh sebab itu, karakter Ummatan Wasathan merupakan jawaban atas berkembangnya paham dan gerakan kelompok intoleran dan mudah

20 Masdar Hilmy, "Whither Indonesia's Islamic Moderatism? A Reexamination on the Moderate Vision of Muhammadiyah and NU," Journal of Indonesian Islam, Volume 07, Number 01 (June 2013), 45.

${ }^{21}$ Wahbah al-Zuhaili, al-Washathiyyah Mathlabun Syar'iyyah, dalam Zuhairi Misrawi, Pandangan Muslim Moderat, (Jakarta: Kompas, 2010), 5.

22 Lihat, Tarmizi Taher, Aspiring for the Middle Path Islam: Religious Harmony in Indonesia (Jakarta: Center for the Study of Islam and Society IAIN Syarif Hidayatullah Jakarta, 1997).

${ }^{23}$ Al-Raghib al-Asfahaniy, Mufradat al-Fadzul Qur'an (Beirut: Darel Qalam, 2009), 869.

${ }^{24}$ Dzul Faqqar 'Ali, Mu'jam al-Wasith (Kairo: ZIB, 1973), 1031.

${ }^{25}$ Jâbir Al-Jazâ'iri, Aisar At-Tafâsîr li Kalâm al - 'Aliy al-Kabîr (Jeddah: Racem Advertising, 1990), Cet. III, 125-126.

${ }^{26}$ Masdar Hilmy, “Quo-Vadis Islam Moderat Indonesia,” Jurnal Miqot, Vol. 36, No. 2 (2012). 
mengkafirkan (takfiri). ${ }^{27}$ Konsep Ummatan Wasathan mengupayakan nilai-nilai ajaran Islam yang moderat dalam kehidupan keagamaan, kemasyarakatan, kebangsaan, dan kenegaraan. Sikap moderat inilah yang menjadi manifestasi ajaran Islam rahmatan lil 'alamin; rahmat bagi segenap alam semesta.

\section{Pendekatan Dakwah}

Pesantren Miftahul Qulub juga melakukan pendekatan dakwah atau misi yang disebut Imam Suprayogo sebagai bentuk faktor penting dalam upaya mengedukasi masyarakat melalui sarana dakwah sehingga terwujud masyarakat yang rukun dan berwawasan keagamaan. ${ }^{28}$ Dakwah atau misi yang dilakukan oleh Pesantren Miftahul Qulub dengan cara mendidik santrinya dan masyarakat dengan pendekatan kultural. Dakwah disampaikan dalam mimbar hari-hari besar kegamaan, melalui tradisi-tradisi masyarakat, seperti rokat tase' (berdoa di pantai bersama nelayan) dam tradisidan budaya Madura lainnya seperti rokat pakarangan (berdoa untuk keselamatan penghuni rumah) dan lainnya.

Pesantren Miftahul Qulub dalam konteks dakwah mengkontekstualisasikan pandangan K.H. Hasyim Asy'ari sebagai perintis Nahdlatul Ulama. Sebagaimana telah dijelaskan oleh Baso, bahwa pesantren dalam dakwahnya harus melakukan: Pertama, pesantren dengan sistem pendidikannya mengajak bangsa untuk mandiri secara ekonomi, politik dan budaya dan dalam kerja pengetahuan. Dalam konteks ini Mohammad Tolchah Hasan (dalam Maskuri Bakri) menjelaskan bahwa kemandirian secara ekonomi, politik dan budaya hanya bisa dilakukan dengan investasi pendidikan. $^{29}$

Kedua, K.H. Hasyim Asy’ari menyebutkan bahwa pendidikan pesantren telah mengajak dan memberikan pesan persatuan bangsa se-Nusantara, bhineka tunggal ika. Dalam konteks ini Baso menjelaskan bahwa kehidupan santri berbaur dengan santri lainnya yang datang dari berbagai daerah di Nusantara, perbedaan etnis, suku dan bahasa menjadikan santri berbaur menjadi satu (united in diversity) polarisasi kehidupan dalam hitrogenitas santri di pesantren ini menjadi modal sosial yang baik dalam menghasilkan generasi yang harmonis, inklusif dan toleran. ${ }^{30}$ Ini artinya acuan dan landasan pendidikan pesantren disandarkan dalam kehidupan bernegara dan bermasyarakat.

\footnotetext{
${ }^{27}$ Muhammad at-Thahir Ibnu 'Âsyûr, Tafsir At-Tahrîr wa al-Tanwir (Tunisia: Dar Shuhnun li al-Nasyr wa al-Tauzi', 1997), 268.

${ }^{28}$ Suprayogo, et al. Merajut Benang Kusut, 9.

29 Maskuri Bakri, Formulasi dan Implementasi Kebijakan Pendidikan Islam: Analisis Kritis terhadap Proses Pembelajaran (Surabaya: Visipres Media, 2017), xvi.

${ }^{30}$ Ahmad Baso, et.al., K.H. Hasyim Asy'ari : Pengabdian seorang Kiai untuk Negeri (Jakarta: Museum Kebangkitan Nasional, 2017), 9.
} 
Mo’tasim, Maskuri Bakri, Djunaidi Mistar, M. Djunaidy Ghony, Nia Indah Purnamasari

Ketiga, pengetahuan diabdikan untuk kepentingan nusa dan bangsa, itu sebabnya pesantren mengajarkan berbagai jenis kebudayaan Nusantara. Dalam konteks ini, penulis ingin meminjam istilah Kiai Mohammad Tijani Djauhari dalam konteks membangun Madura "Membangun Madura bukan membangun di Madura" penulis ganti dengan "Membangun Indonesia bukan membangun di Indonesia". Adagium ini menunjukkan bahwa manusia Indonesia harus menjadi "subjek aktif" yang menentukan hitam putihnya negeri ini. ${ }^{31}$

Keempat, karena dalam sejarah pergaulan muslim sangat rapat dengan bangsa lain, maka pesantren mengajarkan cara bersiasah dan bergaul dengan bangsa lain. Setidaknya ada beberapa hal yang menjadi kelebihan pesantren, diantaranya adalah budaya pesantren. Budaya ini yang menurut Maskuri Bakri seharusnya dikembangkan ke wawasan teknologi. Kemudian Pesantren, dengan budaya tersebut dapatlah tampil secara percaya diri di depan bangsa lain. Dalam hal ini menurut Maskuri, pesantren harus menjaga ketahanan budayanya seiring dengan majunya globalisasi secara pesat. ${ }^{32}$

Kelima, pesantren mengajarkan kepada semua bangsa untuk memaksimalkan potensi ekonomi dan sumber daya negeri ini, itu sebabnya pesantren hadir di tempat-tempat mata air dan sumber kekayaan alam. ${ }^{33}$ Dalam kaitannya dengan gagasan ini, Maskuri menegaskan bahwa pesantren seharusnya tidak diharapkan sekedar memainkan fungsi tradisionalnya tapi juga menjadi pusat kesehatan, pusat pengembangan teknologi tepat guna bagi masyarakat pedesaan, pusat usaha penyelamatan dan pelestarian lingkungan hidup, dan yang lebih penting lagi adalah menjadi pusat pemberdayaan ekonomi masyarakat sekitarnya. Maka dalam konteks yang terakhir ini pesantren terlibat dalam aktivitas vocational dan ekonomi, seperti dalam usaha agribisnis yang mencakup pertanian dan tanaman pangan, peternakan, perikanan, kehutanan, pengembangan industri rumah tangga, atau konveksi, kerajinan tangan, pertokoan, dan koperasi. ${ }^{34}$

Kelima dakwah tersebut di atas menjadi prinsip dan gerakan dakwah baik secara internal pesantren maupun secara eksternal kemasyarakatan. Pesantren melakukan dakwah pendidikan yang menyuarakan kemandirian ekonomi, mengajak dan memberikan pesan persatuan kepada masyarakat dengan spirit ke-NU-an, dan bhineka tunggal ika. Itu sebabnya pesantren Miftahul Qulub mengajarkan berbagai jenis kebudayaan Nusantara. Bersikap terbuka kepada masyarakat berbeda etnis dan agama, merespon kebutuhan masyarakat, dan yang terakhir adalah mengajarkan kepada semua masyarakat untuk memaksimalkan potensi ekonomi dan sumber daya.

\footnotetext{
${ }^{31}$ Mohammad Tijani Djauhari, Membangun Madura (Jakarta: Taj Publishing, 2008), xi.

32 Maskuri Bakri, Dekonstruksi; Jalan Terjal Membangun Negara Ketiga, Perspektif Pendidikan, Pemberdayaan dan Pelayanan Publik (Surabaya: Visi Press Media, 2017), 159.

${ }^{33}$ Baso, et.al., K.H. Hasyim Asy'ari, 9.

${ }^{34}$ Lihat, Bakri, Dekonstruksi, 171. Bandingkan dengan Mohammad Nadzir, "Membangun Pemberdayaan Ekonomi di Pesantren", Economiuca, Volume VI/ Edisi1 (Mei, 2015), 48.
} 


\section{Pendekatan Modal Sosial}

Pendekatan pesantren Miftahul Qulub dalam melakukan adaptasi dalam menciptakan kerukunan yang bertahan lama di Polagan dalam pandangan Bourdieu bahwa survivalitas dapat dikatakan berhasil jika individu atau kelompok mampu mengakumulasi dan menguasai modal sosial yang di dalamnya terdapat tiga aspek: kultural, simbolik, dan ekonomi. ${ }^{35}$ Dalam upaya bertahan hidup, setiap agen (individu, kelompok, maupun institusi) mesti berjuang untuk memperebutkan sumber dan pertaruhan dengan akses terbatas dalam suatu ranah atau arena (field). Bagi Bourdieu, ranah sebagai sebuah arena sosial yang di dalamnya terdapat perjuangan mengumpulkan sekaligus menguasai modalitas sosial tersebut. ${ }^{36}$ Modal yang telah dikumpulkan itu hanya akan membuahkan hasil-hasil dimana ia memproduksi dan mereproduksi. ${ }^{37}$

Modalitas setiap agen (agent) terdiri dari: modal kultural, modal ekonomi, dan modal simbolik. Modal kultural adalah modal yang didapat agen melalui kemampuan yang diciptakan atau diperoleh dengan cara usaha. Wujud nyata dari modal kultural dalam realitas sosial adalah berupa pengetahuan dan cara memperoleh pengetahuan yang dimilikinya itu. ${ }^{38}$ Aspek ini terwakili oleh adanya madrasah yang secara kurikulum telah mengajarkan nilai multikultur melalui pembelajaran Akhlak yang dipelajari di madrasah/lembaga pendidikan. Modal kultur ini juga terkonstruk secara otomatis dalam konfigurasi budaya masyarakat. Saling menghargai budaya dan kultur ini menjadikan perbedaan menyejukkan dan harmonis.

Kemudian modal ekonomi tidak semata bermakna uang atau dana, melainkan juga termasuk modal yang berupa penguasaan atas tanah, sejumlah sumber daya, dan sumber ilmu pengetahuan. Dalam temuan penulis masyarakat etnis Tionghoa di Polagan memiliki modal ekonomi dengan baik, mereka memiliki rumah, bahkan muallaf Tionghoa salah satu warga yang cukup kaya dan pernah merayakan hari besar Islam dengan cukup besar-besaran. Mereka memiliki sumber ekonomi yang relatif kuat. Metafora yang sering digunakan oleh Bourdieu dalam menjelaskan modal ekonomi ini adalah pasar (market). ${ }^{39}$ Dalam realitas sosial, pasar merupakan medan untuk mempertaruhkan segenap modal yang dimiliki oleh agen guna memperoleh keuntungan. Hukum ekonomi konvensional menyebutkan hukum penawaran dan permintaan. Etnis Tionghoa, berdasar modal ekonomi ini, menyiasati bisnis yang digelutinya supaya modal ekonomi terus bertambah. Aspek ini dimiliki etnis Tionghoa di Polagan, sumber pendapatan, jumlah pendapatan, jenis usaha, dan jaringan bisnis mereka.

\footnotetext{
${ }^{35}$ Pierre Bourdieu, In Other Word (Cambridge: Polity Press, 1977), 88.

${ }^{36}$ Richard Jenkins, Membaca Pikiran Pierre Bourdieu, Penj. Nurhadi (Yogyakarta: Kreasi Wacana, 2010), 124.

${ }^{37}$ Pierrie Bourdieu, Distinction; A Social Critique of the Judgement of Taste (New York: Routledge, 2006$), 125$.

38 Jenkins, Membaca Pikiran Pierre Bourdieu, 125.

${ }^{39}$ Bourdieu, Distinction, 113.
} 
Mo'tasim, Maskuri Bakri, Djunaidi Mistar, M. Djunaidy Ghony, Nia Indah Purnamasari

Sedangkan modal simbolik merupakan segenap jenis relasi yang memiliki nilai dan makna dengan pihak lain. ${ }^{40}$ Modal ini mewujud berupa hubungan kekeluargaan, lingkungan sekitar maupun pekerja yang di dalamnya terdapat relasi timbal balik. ${ }^{41}$ Modal simbolik memang berbentuk material tapi tidak dikenali, misalnya berupa: selera berpakaian, logat yang baik, dan gaya. Semua ini bisa berlaku efektif tidak disebabkan oleh kematrialannya, melainkan dari kesalahpengenalan tentang hal ini. ${ }^{42}$ Modal simbolik ini dapat berupa prestise dan kemasyhuran yang didapat dari keluarga atau nama yang disandangnya, maka aspek ini akan digunakan untuk menjelaskan jaringan kekerabatan masyarakat multi etnis dan agama, kekuasaan kultural yang dimiliki, keturunan, dan silsilah kefamilian mereka. Dengan landasan teori yang telah dipaparkan di atas, masyarakat multi etnis dan agama dapat dijabarkan bahwa secara simbolik logat dan panggilan sudah menjadi hal yang biasa di kalangan masyarakat umum. Simbol ritual keagamaan mereka seperti lilin juga dibantu pemasangannya oleh masyarakat yang bekerja di Vihara. Mereka menganggap dan mengatakan tidak ada pelecehan simbolik ritual keagamaan, budaya dan tradisi etnis dan agama.

\section{Pendekatan Modal Politik}

Selain modal sosial yang terdiri dari kultur, ekonomi dan simbolik, ada satu temuan yang sangat penting untuk dikemukakan, yaitu modalpolitik. Modal politik dalam hal ini adalah konstelasi politik nasional yang berdampak pada terciptanya harmonisasi masyarakat multikultural.Dalam sejarahnya, pada masa Presiden Soekarno, etnis Tionghoa masih belum dapat menunjukkan eksistensinya. Hal tersebut tercermin dalam beberapa kebijakan seperti masalah kepemilikan tanah oleh keturunan Tionghoa sebagai warisan dari ibunya yang pribumi diambil pemerintah dan pada tahun 1953. Setiono dalam Felicia mengatakan, bahwa pada tahun 1959, Presiden Soekarno menandatangani Peraturan Pemerintah No.10 yang berisi mengenai larangan bagi orang-orang asing (khususnya orang Tionghoa) untuk melakukan kegiatan ekonomi di daerah-daerah tertentu. Meskipun demikian, Soekarno masih memberi kelonggaran dengan mengizinkan berdirinya organisasi-organisasi politik dan sosial bagi masyarakat Tionghoa seperti Partai Demokrasi Tionghoa Indonesia (PDTI) dan Perhimpunan Buddhis Indonesia (PERBUDHI). ${ }^{43}$

Di era Orde Baru, etnis Tionghoa mendapat perlakuan lebih diskriminatif. Inpres Nomor 14 Tahun 1967 menjadi bukti, di manatermaktub: 1) Aturan penggantian nama; 2) Melarang segala bentuk penerbitan dengan bahasa serta aksara China. Larangan penggunaan bahasa Mandarin

\footnotetext{
${ }^{40}$ Bourdieu, Distinction, 125.

${ }^{41}$ Pierrie Bourdieu, Outline Of Theory of Practice (New York: Cambridge University Press, 1989), 171.

${ }^{42}$ Richard Harker, Cheelen Mahar, (Habitus X Modal) + Ranah = Praktik (Yogyakarta: Jalasutra, 2005), 6.

${ }^{43}$ Felicia Tania K, et.al. "Studi Ikonografi Panofsky pada Ornamen Interior Vihara Avalokitesvara Pamekasan, Madura," Jurnal Intra, Vol. 5, No. 2, (2017): 182-190.
} 
dalam berkomunikasi di depan umum; 3) Membatasi kegiatan-kegiatan keagamaan hanya di lingkungan keluarga; 4) Tidak mengizinkan pagelaran dalam perayaan hari raya tradisional Tionghoa; 5) Pelarangan sekolah-sekolah Tionghoa dan menganjurkan anak-anak Tionghoa untuk masuk ke sekolah umum. ${ }^{44}$

Di era Reformasi, diskriminasi terhadap etnis Tionghoa dihilangkan sejak Presiden K.H Abdurahman Wahid mengeluarkan Keppres Nomor 6 Tahun 2000 yang mencabut Inpres Nomor 14 tahun 1967. Etnis Tionghoa beserta kebudayaannya bisa merasakan kebebasan untuk mengekspresikan eksistensinya. Hal tersebut diperkuat dengan dikeluarkannya UU No.40/2008 tentang Penghapusan Diskriminasi Ras dan Etnis (PDRE) pada masa pemerintahan Presiden Susilo Bambang Yudhoyono.

Sejak itulah, Vihara direnovasi dengan berbagai ornamen yang kental akan budaya Tionghoa. ${ }^{45}$ Vihara Avalokitesvara ramai dikunjungi oleh beragam kalangan. Selain adanya mushola didalam Vihara, juga terdapat Pura yang diperuntukan bagi umat Hindu yang dibangun pada tahun 1985. Semua umat baik Buddha, Islam, Hindu, Khonghucu dan Tao dapat hidup berdampingan ketika Vihara mengadakan perayaan keagamaan Buddha. Umat Islam selalu berbaur ke dalam perayaan tersebut. Bahkan, sebagian mereka menjadi panitia kegiatan yang diselenggarakan pihak yayasan. ${ }^{46}$

\section{Proses Adaptasi Nilai-nilai Multikultural Pesantren Miftahul Qulub}

Untuk mengetahui dan mengkaji lebih dalam tentang konstruksi kerukunan dalam masyarakat multi etnis dan agama, penulis langsung mendatangi pesantren Miftahul Qulub mengingat menurut pengakuan masyarakat bahwa pesantren ini berpengaruh terhadap realitas kerukunan masyarakat multi etnis dan agama. Penulis melakukan wawancara seputar kajian penelitian tentang bagaimana realitas keberagaman dapat hidup tumbuh dan harmonis dalam satu desa yang ada di dalamnya empat agama dan multi etnis, yang antar mereka dapat hidup berdampingan tanpa adanya pelanggaran sosial seperti diskriminasi dan kekerasan sosial dan agama.

Salah satu informan kunci adalah pengasuh pesantren Miftahul Qulub mengatakan bahwa pesantren melakukan adaptasi diri dengan masyarakat sekitar. Hal ini dilakukan dengan mengadaptasi kebutuhan masyarakat terhadap SDM (sumberdaya manusia) yang diinginkan di tengah masyarakat sebagai bentuk outcome pesantren yang seyogyanya menjawab kebutuhan masyarakat sekitar.

\footnotetext{
44 Tania, "Studi Ikonografi Panofsky," 188.

45 Tania, "Studi Ikonografi Panofsky," 189.

${ }^{46}$ Tania, "Studi Ikonografi Panofsky," 190.
} 
Mo’tasim, Maskuri Bakri, Djunaidi Mistar, M. Djunaidy Ghony, Nia Indah Purnamasari

Adaptasi ini arah pendidikan yang berbasis agama dan kebudayaan sehingga alumni pesantren ini menjadi gampang diterima oleh masyarakat multi etnis dan agama. ${ }^{47}$

Adaptasi ini dilakukan sejak 1960 tahun silam di mana pesantren ini dirintis untuk memberikan pendidikan kepada masyarakat Polagan, dengan mengkonstruk pembelajaran dengan pendekatan agama dan budaya dengan kajian kitab kuning seperti kajian kitab-kitab ahlussunnah waljamaah di antaranya kitab Risalah Ahlusunnah wal jamaah karya KH. Hasyim As'ari, dan kitab-kitab lainnya yang diajarkan oleh pesantren NU seperti kitab Aqidatul Awam, Kitab ta'lim muta'allim, dan kitab taqrib, taysirul khollak dst. ${ }^{48}$

Beberapa materi pembelajaran kitab kuning di atas menurut salah satu pengasuh pesantren sudah cukup untuk mengajarkan akhlak mendasar tentang bagaimana seharusnya santri bersikap dalam masyarakat Polagan yang multi etnis dan agama. Kajian kitab-kitab tersebut menjadi wajib diajarkan kepada santri baik yang muqim maupun yang tidak. Sehingga dapat dipastikan semua santri telah mengalami pembelajaran kitab. Inilah menurut salah satu pengasuh bahwa praktik akhlak santri telah dibentuk sejak dini melalui pesantren. ${ }^{49}$

Menurut salah satu tokoh masyarakat Polagan yakni kepala desa Polagan mengatakan bahwa peran pesantren Miftahul Qulub dalam menciptakan kerukunan masyarakat Polagan dalam konteks pendidikan sangatlah besar. Pesantren ini menurutnya tidak hanya mendidik dan menyiapkan peserta didiknya namun juga mendidik masyarakat secara umum. Pesantren ini berperan kedalam (internal) dan juga keluar eksternal. Apalagi hampir 70 persen masyarakat Polagan adalah merupakan santri alumni dari pesantren tersebut. ${ }^{50}$

"Alhamdulillah eksistensi pesantren Miftahul Qulub sampai hari ini masih masyarakat rasakan sebagai lembaga yang mendidik santri dan juga mengayomi masyarakat. Pesantren ini memberikan adaptasi Pendidikan Agama Islam yang menyeru kepada kerukunan dan toleransi antar masyarakat multi etnis dan agama. Lewat tradisi koloman, dan tradisi keagamaan lainnya seperti peringatan maulid Nabi atau peringatan hari besar Islam lainnya, Pesantren selalu mengedukasi masyarakat akan pentingnya kebersamaan dalam keberagaman.."51

Salah satu masyarakat penjaga vihara, mengatakan bahwa pesantren dan tokoh agama di Polagan sangat akomodatif, sehingga masyarakat menerima keberadaan keberagaman etnis dan agama.

\begin{abstract}
"Saya sangat menerima keberagaman masyarakat ini, salah satu buktinya saya ini beragama Islam, orang tua saya mempunyai keyakinan beragama yang berbeda, Bapak saya Yulianto (Lea Cheng Yu) beragama Katolik sedangkan Ibu saya Halima (Neo Sing Cing)beragama Budha, bahkan mertua saya K. Aminuddin dan Ny. Nasriyah adalah seorang kiai. Hal ini menurut saya menjadi bukti bagaimana Masyarakat Desa Polagan menerima adanya perbedaan etnis dan agama."
\end{abstract}

\footnotetext{
${ }^{47}$ Kiai MHD, Wawancara, Pamekasan, 15 Desember 2019

${ }^{48}$ KiaiMHD, Wawancara, Pamekasan, 15 Desember 2019

${ }^{49}$ LKM, Wawancara, Pamekasan, , 15 Desember 2019

50 SWJ, Wawancara, Pamekasan, 15 Desember 2019

51 SWJ, Wawancara, Pamekasan, 16 Desember 2019

${ }^{52}$ ASN, Wawancara, Pamekasan, 7 April 2019
} 
Pengakuan Adi Sutrisno secara otomastis membuat penulis ingin menggali lebih dalam bagaimana dirinya dapat beradaptasi dan hidup secara harmonis dengan keluarganya yang berbeda agama. Sebenarnya bagaimana masyarakat Polagan menerima keberadaan keberagaman etnis dan agama. Kemudian dirinya menjelaskan bahwa masyarakat keturunan Tionghoa sudah sangat melebur dengan masyarakat asli (pribumi), hal ini diwujudkan dari semua kegitan-kegiatan keagamaan dan adat mereka selalu berpartisipasi, semisal koloman, muslimatan dan kegiatan-kegiatan agama dan adat lainnya. Menurutnya juga segala bentuk kebudayaan yang dijalankan dan tradisi yang tetap jaga itu sama sekali tidak mengganggu terhadap aktifitas warga asli, bahkan saling mendukung menjadi sebuah kekayaan masyarakat Desa.

Kemudian, Sutrisno juga mengatakan bahwa di masyarakat telah terjadi kolaborasi budaya antar masyarakat setempat dan etnis Tionghoa, seperti dikatakan berikut ini:

"Disini tidak ada sekat-sekat antara kami dengan masyarakat asli, tidak ada yang membedakan antara kami dengan yang lain, banhkan keturunan dari kami yang berkeluarga dengan masyarakat asli",53

Menurut Sutrisno ada sistem atau aturan yang membentuk masyarakat menjadi rukun yaitu kesadaran individu dan kelompok dan juga peran kepada desa. Ada koloman, tahlilan dan madrasah yang membuat kerukunan dalam masyarakat ini menjadi rukun. Sehingga Ada pribahasa Madura yang berbunyi "Jhung Sae-an" yang artinya berusaha membalas kebaikan dengan lebih baik yang akhirnya menjadi pola hubungan dan kerukunan antar masyarakat.

Tentang kerukunan antar etnis dan agama juga dijelaskan oleh pengurus vihara, KSL mengatakan bahwa dalam sejarah, belum pernah terjadi kekerasan di lingkungan vihara.

"Vihara ini sudah berdiri kurang lebih 3 Abad yang lalu dan Tidak Pernah terjadi konflik atas nama etnis dan budaya, Dulu masih awal-awal Vihara ini dibangun, dan waktu itu masih baru ada kabar mau ada Belanda masuk ke sini, memang sempat terjadi kekerasan, tapi kekerasan itu bukan atas nama etnis dan agama. Tapi motifnya pencurian." 54

KSL yang menjelaskan bahwa pernah terjadi pengrusakan terhadap vihara, yang dilakukan oleh orang yang tidak dikenal. Mereka menyangka para pendahulunya menyimpan harta di bawah lantai vihara sehingga lantai vihara rusak dan beberapa arca juga hilang. Perusakan vihara ini, jelas KSL jelas bermotif perampokan yang dilakukan oleh orang di luar desa atau masyarakat lingkungan vihara. Bukan bermotif kekerasan etnis dan agama.

Kemudian KSL juga menerangkan bahwa hubungan etnis Tionghoa dengan beragama nonmuslim dan muslim sangat harmonis dan rukun.

\footnotetext{
${ }^{53}$ Adi Sutrisno, Wawancara, Pamekasan, 7 April 2019
}

${ }^{54}$ KSL, Wawancara, Pamekasan, 7 April 2019 
Mo’tasim, Maskuri Bakri, Djunaidi Mistar, M. Djunaidy Ghony, Nia Indah Purnamasari

"Hubungan antar ummat beragama di sini sangat Baik, bahkan di vihara ini juga ada Mushalla bagi yang Muslim, Candi tau Pura bagi yang Hindu, klenteng atau Dhammasala bagi yang Budha, Lithang bagi yang konghucu. Empat tempat ibadah ini ada dalam komplek Vihara tidak ada pembatas antar keempat tempat ibadah tersebut kecuali hanya yang diperlukan saja. Kerukunan ini sepertinya sudah warisan dari mbah buyut dan pendahulu kami. Bahkan pendirian Vihara ini tidak lepas dari peran masyarakat sekitar yang ikut menemukan Arca Dewi Kwuan Inn. "55

Seberapa besar hubungan antar umat vihara dan Muslim, penulis pernah diberhentikan oleh sejumlah remaja Muslim yang berjaga di depan pintu gerbang vihara. Mereka memberhentikan penulis saat penulis berusaha memasuki vihara, Sejumlah remaja Muslim tersebut meminta penulis untuk tidak masuk vihara, karena sedang pemujaan doa sedang berlangsung dan tidak mengganggu ritual ibadah mereka. Penulis kemudian berhenti dan kembali pulang. Dalam hati penulis bergumam, Hebat! Ternyata Muslim di kompleks ini sangat menjaga kerukunan dan kenyamanan beribadah masyarakat yang berbeda dengan komunitasnya.

KSL menguatkan keyakinan penulis, saat penulis menanyakan tentang sikap rukun dan toleran masyarakat vihara dengan masyarakat sekitar yang multi etnis dan agama. Berikut keterangan KSL :

\begin{abstract}
"Sebenarnya semua agama mengajarkan yang sama tentang bab kerukunan di dalam dalam agama Hindu dalam Sabda Suci Weda juga diajarkan kerukunan, di Agama Budha dalam Tripitaka juga diajarkan kerukunan, kemudian Konghucu dalam Wu Jing juga diajarkan tentang kerukunan antar ummat beragama dan dalam Islam sendiri juga diajarakan untuk hidup rukun dan damai. Jadi apa yang mau dibuat konflik?"56
\end{abstract}

Pengurus vihara itu juga menegaskan bahwa sudah terjadi konfigurasi sosial dan perkawinan silang antar etnis Tionghoa dan penduduk asli, yang akhirnya membuat hubungan masyarakat multi etnis dan agama menjadi kuat dan harmonis. Pengakuan KSL ini dikuatkan oleh pengakuan tokoh masyarakat, Kiai MHD yang mengaku pihaknya pernah menikahkan etnis Tioghoa dengan penduduk setempat. "Saya pernah ke Solo untuk membantu pernikahan mereka, pernah juga Bali dan tempat lainnya untuk membantu pernikahan mereka." 57

Konvergensi budaya antar masyarakat multi etnis dan agama menjadikan sebuah heterogenitas masyarakat menjadi lebih harmonis. Akulturasi budaya masyarakat multi etnis dan agama menjadikan masyarakat menerima budaya antar masyarakat secara baik. Mereka hidup rukun dan inklusif.

"Masyarakat keturunan Tionghoa sudah sangat melebur dengan masyarakat asli (pribumi), hal ini
diwujudkan dari semua kegitan-kegiatan keagamaan dan adat mereka selalu berpartisipasi, semisal
koloman, muslimatan dan kegiatan-kegiatan agama dan adat lainnya.Segala bentuk kebudayaan yang

\footnotetext{
${ }^{55} \mathrm{KSL}$, Wawancara, Pamekasan, 7 April 2019

${ }^{56} \mathrm{KSL}$, Wawancara, Pamekasan, 7 April 2019

${ }^{57}$ Kiai MHD, Wawancara, Pamekasan, 6 April 2019. 
kami jalankan dan tradisi yang tetap jaga itu sama sekali tidak mengganggu terhadap aktifitas warga asli, bahkan saling mendukung menjadi sebuah kekayaan Masyarakat Desa Polagan". ${ }^{58}$

Tentang konvergensi masyarakat Polagan, kepala desa mendukung pernyataan Ibu GYT, bahwa konvergensi merupakan akulturasi budaya sebuah masyarakat, namun tidak melupakan identitas budaya asli. Masyarakat menerima dan berbaur dengan budaya etnis dan agama lainnya, namun mereka tetap mempertahankan identitas keislaman mereka. Sebagai contoh, ketika masyarakat Tionghoa merayakan hari besar, komunitas Muslim mendapingi dan membantu kelancaran acara. ${ }^{59}$ Kiai ASM selaku tokoh agama, juga mempertegas bahwa pihaknya pernah diminta untuk menghadiri salah satu acara perayaan di vihara. Sesekali, Kiai ASM diminta memberikan sambutan, bahkan dia juga kerap diminta untuk berdoa. ${ }^{60}$

Maka dalam kajian ini, terdapat nilai toleransi (tasamuh) dan saling menghargai antar masyarakat multi etnis dan agama. Selain nilai toleransi penulis juga menyimpulkan ada nilai moderatisme masyakarakat (wasathiyyah) yang mengedepankan kepentingan masyarakat umum dan mengenyampingkan ego kelompok masing-masing serta nilai tolong menolong antar masyarakat (taawun).

Untuk mengungkap lebih jauh kuatnya kerukunan yang bertahan hingga kurang lebih 3 abad ini yang berlangsung secara harmonis, penulis berusaha mendalami faktor-faktor yang menguatkan sistem kerukunan ini bertahan, di antaranya: Pertama, kegiatan Koloman. Pesantren Miftahul Qulub mengakomodir adanya perkumpulan masyarakat atau yang disebut dengan Koloman, adalah berkumpulnya masyarakat desa Polagan pada malam Jumat dalam rangka tahlilan dan doa bersama. Koloman ini dimanfaatkan oleh Kiai dan tokoh masyarakat untuk menyampaikan pesan nilai toleransi dan sikap saling menghormati antar masyarakat. Koloman adalah tradisi silaturrahim yang di dalanya juga ada acara pengajian tempat Masyarakat Desa Polagan menimba ilmu agama. ${ }^{61}$ Kedua, menjaga vihara. Upaya adaptasi pesantren Miftahul Qulub dalam pendidikan kerukunan masyarakat sebenarnya untuk menjawab realitas spirit kerukunan dan toleransi yang didengungkan oleh pihak vihara. Pesantren dan vihara ini memiliki peran strategis dalam mempengaruhi kerukunan antar masyarakat Polagan. Kegiatan keagamaan yang berpusat di masjid madrasah Miftahul Qulub III, seperti khotbah Jumat dan kegiatan keagamaan disampaikan dengan spirit kerukunan dan toleransi keagamaan dan etnisitas yang menjadi fakta sosial masyarakat. ${ }^{62}$ Ketiga, menjaga keamanan tahun baru Imlek. Bentuk adaptasi keamanan yang dilakukan oleh pesantren adalah dengan memberikan

\footnotetext{
${ }^{58}$ GYT, Wawancara, Pamekasan, 4 April 2019.

${ }^{59}$ SWJ, Wawancara, Pamekasan, 4 April 2019.

${ }^{60}$ Kiai ASM, Wawancara, Pamekasan, 4 April 2019

${ }^{61}$ SWJ, Wawancara, Pamekasan, 8 April 2019.

62 LKN, Wawancara, Pamekasan, 16 Desember 2019
} 
Mo’tasim, Maskuri Bakri, Djunaidi Mistar, M. Djunaidy Ghony, Nia Indah Purnamasari

himbauan bahwa masyarakat tidak boleh mengganggu proses perayaan Imlek. Walaupun himbauan ini hanya sebatas diucapkan oleh Kiai pada kesempatan pertemuan Koloman mingguan ataupun saat khutbah Jumat di masjid dan bukan himbauan tertulis. Mengingat sebenarnya belum pernah terjadi gangguan saat pelaksanaan perayaan Imlek tersebut. ${ }^{63}$ Keempat, mendorong pendidikan kerukunan. Kiai pesantren Miftahul Qulub selalu mendorong pendidikan kerukunan dan toleransi juga dilakukan melalui pendidikan keluarga. Pengaruh pendidikan keluarga terhadap kerukunan beragama sangat kuat. Di dalam keluarga, masyarakat Polagan harus dipupuk pengetahuan agama dan sikap toleransi. ${ }^{64}$

\section{Adaptasi Nilai Multikultural sebagai Dasar Kerukunan Masyarakat Multi Etnis dan Multi Agama}

Adaptasi pesantren dalam pendidikan disebut dalam teori Parsons sebagai integration ${ }^{65}$ yaitu dimana pesantren sebagai subsistem kultural memelihara pendidikan masyarakat. Modal kerukunan yang diadaptasi oleh pesantren tersebut di atas secara rinci dapat dijelaskan bahwa pesantren Miftahul Qulub secara internal telah mengadaptasi pendidikan multikultural melalui pembelajaran di pesantren baik teoritis (kajian kitab) maupun praktis (budaya hidup di dalam pesantren) kepada para santri.

1. Materi Pembelajaran

Materi yang diajarkan di madrasah ini, salah satunya adalah kitab akhlak "Taysiru alKhollaq" dan "akhlak lil banin" setelah melakukan pendalaman materi pada kedua kitab akhlak tersebut, didapatkan hal-hal berikut ini :

a. Kitab Taysiru al-Khalaq

Kitab Taysiru al-Khalaq adalah kitab yang berisi tentang kajian akhlak, baik terhadap Allah maupun terhadap sesama manusia. Kitab ini ditulis oleh seorang ulama yang bernama Hafidz Hasan al-Mas'udi ini berisi sebanyak 55 halaman dan berisi sebanyak 33 tema ini sangat ringkas dan mudah dipelajari. Kitab ini relevan untuk dijadikan pembelajaran bagi pemula dalam mempelajari akhlak. Hasil penelitian menunjukan bahwa konsep pendidikan akhlak dalam kitab ini mencakup; akhlak kepada Allah, adab guru dan murid, akhlak kepada diri sendiri dan orang lain, akhlak mahmudah dan akhlak madzmumah. Konsep pendidikan akhlak pada kitab ini dapat menjadi solusi dalam memperbaiki akhlak di berbagai bidang.

b. Kitab Akhlaq lil Banin

Kitab Akhlaq lil Banin merupakan salah satu kitab yang sering digunakan untuk membentuk akhlak santri di beberapa pesantren di Indonesia. Kitab ini membahas terkait beberapa akhlak yang harus dikerjakan dan juga yang harus ditinggalkan. Pembentukan akhlak dalam kitab ini tidak hanya karakter islami saja, tetapi juga penguatan ibadah. Sebagai

\footnotetext{
63 LKN, Wawancara, Pamekasan, 16 Desember 2019

${ }^{64} \mathrm{KSL}$, Wawancara, Pamekasan, 8 April 2019

${ }^{65}$ Ritzer \& Douglas, Teori Sosiologi Dari Teori Sosiologi Klasik Sampai Perkembangan Terakhir, 257.
} 
contoh, dalam etika istikharah dan bermusyawarah, anak diajarkan untuk berserah diri kepada Allah Swt. Kitab Akhlaq lil Banin memuat terkait akhlak keseharian bagi anak laki-laki seperti akhlak berjalan, duduk, berbicara, makan bersama, menjenguk orang sakit, serta akhlak dalam melakukan silaturahim. ${ }^{66}$

Untuk menganalisis dimensi multikuralisme dalam pendidikan madrasah, penulis menggunakan teori James A. Banks. Banks menyebutkan ada 5 dimensi pendidikan multikultural, diantaranya: 1) Content integration (integrasi pendidikan multikultural dalam kurikulum), yaitu bagaimana seorang pendidik dalam pembelajaran dapat membawa dan mengisi konten pedagogik dengan materi keragaman budaya. 2) The knowledge contruction process (kontruksi ilmu pengetahuan). Seorang pendidik harus membantu siswa memahami, melakukan investigasi dan menentukan asumsi kultural, sumber atau sejarah kebudayaan, dan paradigma kultural yang mempengaruhi kontruksi pengetahuan siswa. 3) Prejudice reduction (pengurangan prasangka). Dimensi ini berfokus pada karakteristik siswa, khususnya dalam perilaku rasisme. 4) An equity pedagogy (pedagogik kesetaraan). Ini adalah bentuk kesetaraan antara guru dan siswa, baik yang berlatarbelakang perbedaan gender, etnis, ras, budaya dan kelompok sosial. ${ }^{67}$ 5) An empowering School culture and social structure (pembedayaan budaya sekolah dan struktur sosial), adalah bentuk pengelompokan dimana siswa dapat berpartisipasi dalam berbagai kegiatan sekolah. Sehingga dapat menguatkan hubungan antar etnis, ras, dan kelompok sosial. ${ }^{68}$

Diagram 1. Dimensi Pendidikan Multikultural James A. Banks

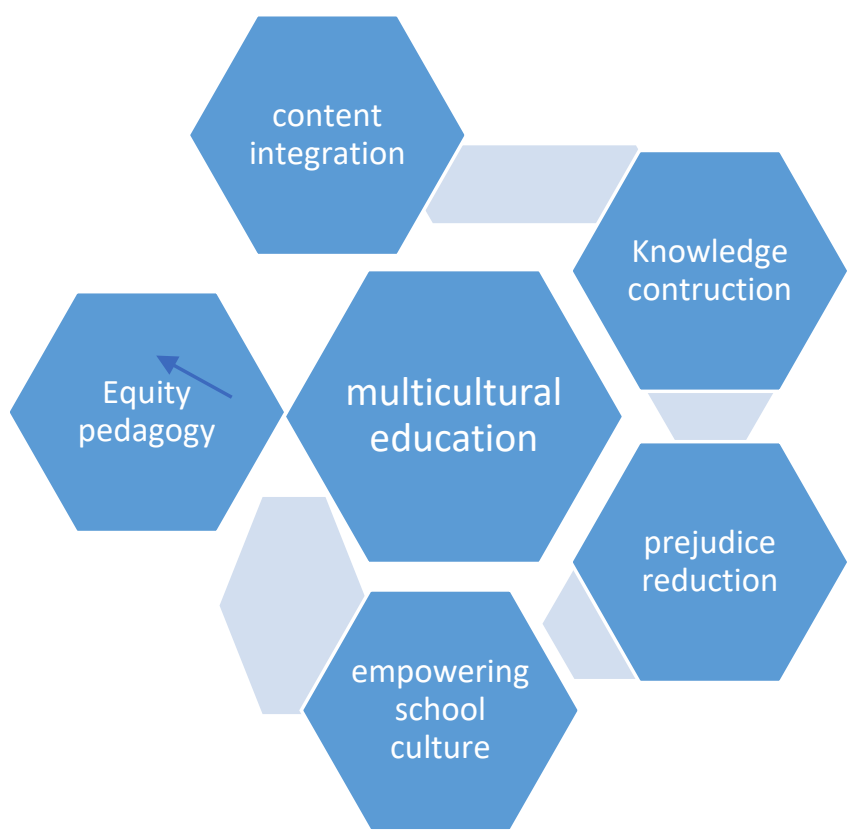

\footnotetext{
${ }^{66}$ Ritzer \& Douglas, Teori Sosiologi Dari Teori Sosiologi Klasik Sampai Perkembangan Terakhir, 257

${ }^{67}$ H.A.R. Tilaar, Multikulturalisme: Tantangan-tantangan Global Masa Depan dalam Transformasi Pendidikan Nasional (Jakarta: Gramedia Widiasarana Indonesia, 2004), 140.

${ }^{68}$ Banks, Multicultural Education, 22.
} 
Mo’tasim, Maskuri Bakri, Djunaidi Mistar, M. Djunaidy Ghony, Nia Indah Purnamasari

Mempertegas apa yang dinyatakan Banks, Gus Dur (dalam Munif) menyatakan bahwa peradaban dunia dapat dilestarikan dengan baik apabila tersemai nilai-nilai multikulturalisme, seperti toleransi, saling menghargai, mengutamakan silaturahim, pendekatan dialog, sikap humanis, menyayangi kaum minoritas, menjaga persatuan dan perdamaian, serta menjaga substansi budaya lokal. ${ }^{69}$ Sementara, Tholchah Hasan lebih menekankan bahwa nilai-nilai yang harus ada di tengah masyarakat adalah komitmen hidup bersama, bekerjasama, saling menghormati, gotong royong, dan saling menjaga perdamaian. ${ }^{70}$

Konsep dasar internalisasi nilai-nilai multikultural dalam desain pendidikan Islam berdasarkan pengembangan kurikulum begitu urgen. Karena kurikulum dapat dipahami dalam arti sempit sekaligus komprehensif. Kurikulum dalam arti yang sempit merupakan kurikulum transformasi ilmu kepada anak didik. Sementara secara konprehensif, kurikulum dipahami sebagai semua bentuk pengalaman yang baik di sekolah ataupun di luar sekolah. Nilai pendidikan multikultural didasarkan pada masyarakat yang memberikan apresiasi kepada keragaman dan perbedaan. Pada saat yang sama, masyarakat harus menciptakan perdamaian, menjaga Hak Asasi Manusia dan menegakkan pilar demokrasi.

Dalam konteks kemajuan dan mutu lembaga pendidikan, atau eksistensi dan survavilitas suatu institusi penulis menggunakan teoritoleransi ekonominya Corneo \& Jeanne. Dalam teorinya, mereka mengatakan bahwa anak yang dari kecil mendapatkan pendidikan toleransi, baik dari orangtua maupun lingkungan, akan mudah mendapatkan kesempatan bekerja dan meningkatkan dan mempertahankan usahanya dibandingkan dengan yang berkepribadian intoleran. ${ }^{71}$ Subtansinya, dalam konteks penelitian ini adalah teori toleransi Corneo \& Jeanne dapat dijadikan landasan bagaimana kemudian suatu fenomena dapat survive karena hubungan yang ada di dalamnya terjalin dengan toleransi, humanis. Tanpa toleransi suatu fenomena dalam hal ini adalah institusi akan mengalami kemunduran dan kemerosotan bahkan sirna.

\section{Keteladanan Kiai}

Kiai $^{72}$ memberikan pesan pendidikan kepada masyarakat dengan langsung memberikan keteladan yang baik dalam menerjemahkan cara hidup dalam keberagaman etnis dan agama. Penulis menganalisis sebuah metode transformasi pesan pendidikan dalam konteks pendidikan multikultural. Beragam metode digunakan dalam pendidikan Islam, diantaranya adalah: 1) al-

${ }^{69}$ Munif, Multikulturalisme dalam Pendidikan Madrasah; Nilai, Implikasi dan Model Pengembangan (Surabaya: Imtiyaz, 2016), 42.

${ }^{70}$ Mohammad Tholchah Hasan, Pendidikan Multikultural sebagai Opsi Penanggulangan Terorisme(Malang: Lembaga Penerbitan UNISMA, 2016), 4.

${ }^{71}$ Giacomo Corneo and Olivier Jeanne, "A theory of Tolerance", Journal of Public Economics, Vol. 93, Issue 5 (2009): 691-702.

72 Kiai Pesantren Miftahul Qulub atau Kiai yang ada di masyarakat Polagan yang juga merupakan alumnus Pesantren Miftahul Qulub 
Awamiru wa an-Nawahy (perintah dan larangan); 2) Taqdimu al-Qudwah al-Toyyibah (Pendidikan keteladanan); 3) Al-Tsawabu wa al-l'qobu (reward and punishment); 4) Al-lyha'u (direct method) atau metode langsung; 5) Metode Qisshoh (bercerita). ${ }^{73}$ Beberapa metode tersebut senada dengan pendapat Haris, bahwa metode pendidikan Islamyang efektif adalah keteladanan, pembiasaan, ibrar dan mau'izhah, metode perumpamaan, metode targhib dan tarhib, dan metode hiwar (percakapan). ${ }^{74}$ Sebagai penegas, Imam al-Ghazali mengingatkan bahwa keteladanan orangtua dan tokoh masyarakat begitu penting dalam memberikan edukasi baik di lingkungan keluarga, lembaga pendidikan maupun masyarakat. ${ }^{75}$ Dalam konteks penelitian ini, kiai dan para tokoh lintas agama mengutamakan keteladanan (Taqdimu al-Qudwah al-Toyyibah). Kiai telah memberikan contoh yang baik dalam setiap perkataan dan perbuatan dalam kehidupan mayarakat yang heterogen di Pamekasan. Sehingga, sebagai figur sentral di pesantren dan tokoh di tengah masyarakat, kiai dijadikan sebagai role model oleh santri dan masyarakat.

Adaptasi nilai multikultural pesantren Mifahul Qulub dalam menciptakan kerukunan masyarakat Polagan merupakan rekonstruksi teori Imam Suprayogo, bahwa pesantren Miftahul Qulub melakukan pendekatan-pendekatan dalam proses adaptasi yaitu pendekatan tradisi kemasyarakatan, mazhab moderat, dakwah dan modal sosial. Pendekatan modal sosial inilah yang menjadi temuan baru dalam penelitian ini. Pesantren Miftahul Qulub melakukan adaptasi secara internal dan eksternal. Adaptasi internal menerangkan tentang adaptasi pembelajaran berbasis realitas sosial budaya dan adaptasi modal kultur, sosial, ekonomi dan simbolik. Sementara, adaptasi secara eksternal, pesantren ini membangun madrasah binaan, kegiatan koloman (perkumpulan yasin tahlil), menjaga keamanan vihara dan tahun baru Imlek, mendorong pendidikan kerukunan melalui keluarga dan keteladanan tokoh agama. Adaptasi tersebut merupakan aktualisasi dari pembudayaan nilai keislaman dan spirit ke-NU-an dalam kerukunan masyarakat multi etnis dan agama.

Temuan diatas memperkuat teori adaptasi fungsionalisme struktural Talcott Parsons yang dikenal dengan skema AGIL (Adaptation, Goal Attainment, Integration, Latency). Dalam adaptation, ada sebuah sistem yang harus memenuhi kebutuhan situasional yang datang dari luar, ia harus beradaptasi dengan lingkungan, kemudian lingkungan menyesuaikan dengan kebutuhankebutuhannya. Pencapaian tujuan atau goal attainment adalah sebuah sistem yang harus mendefinisikan dan mencapai tujuan utamanya. Integrasi (integration) merupakan sistem yang harus mengatur hubungan yang menjadi komponen dan mengatur hubungan ketiga. Terakhir, latensi (latency) adalah pemeliharaan pola yang dapat mempertahankan budaya dan motivasi. Proses adaptasi ini juga merekonstruksi teori Pierrie Bourdieu yang berpandangan bahwa survivalitas dapat

\footnotetext{
${ }^{73}$ Abdul Ghina A'bbud \& Hasan Ibrahim A'dul A'l, at-Tarbiyah al-Islamiyah wa tahaddiyat al-Asyr (Mesir: Darul fiqr alA'roby, 1990), 468.

${ }^{74}$ Abd. Haris, Pendidikan Karakter Berbasis Tauhid; Sebuah Pendekatan Filosofis (Sidoarjo: Afkarpress, 2012), 28.

${ }^{75}$ Abu Hamid al-Ghazali, Ihya Ulumiddin, Jilid III (Beirut: Dar alFikr, t.th), 69-70.
} 
Mo’tasim, Maskuri Bakri, Djunaidi Mistar, M. Djunaidy Ghony, Nia Indah Purnamasari

dicapai apabila seseorang atau suatu kelompok mampu mengakumulasi dan menguasai modal sosial yang di dalamnya terdapat tiga bagian modal: modal kultural, simbolik, dan ekonomi. Penelitian menambahkan aspek politik sebagai modal yang mempengaruhi ketahanan kerukunan masyarakat multi etnis dan multi agama di desa Pologan kabupaten Pamekasan Madura.

\section{E. Kesimpulan}

Pada bagian ini, penulis menyimpulkan bahwa proses adaptasi yang dilakukan pesantren Miftahul Qulub melalui beberapa pendekatan seperti: tradisi sosial kemasyarakatan, madzhab, dakwah dan modal sosial. Adaptasi nilai-nilai multikultural dilakukan secara internal dan eksternal. Secara internal, pesantren melakukan adaptasi pembelajaran berbasis pendidikan multikultural sebagai asas adaptation dan integration. Secara eksternal, pesantren Miftahul Qulub melakukan pembelajaran berbasis nilai-nilai multikulturual pada empat madrasah yang dibangun di tengah masyarakat multi etnis dan agama. Untuk membangun komunikasi sosial, pesantren menyelenggarakan koloman (perkumpulan yasin tahlil) secara rutin. Nilai toleransi diimplementasikan dengan melakukan perlindungan terhadap vihara (goal attainment). Sementara, dalam aspek edukasi, pesantren Miftahul Qulub menekankan pendidikan keluarga (integration) dan keteladanan tokoh agama (latency). Proses adaptasi tersebut adalah aktualisasi dari pembudayaan nilai keislaman ala Nahdhatul Ulama yang melekat pada pesantren. Spirit ke-NU-an inilah yang membuat pesantren begitu mudah membaur dengan masyarakat. Di sisi lain, pesantren Miftahul Qulub menjadikan proses pembelajaran berbasis masyarakat. Sehingga, kurikulum dan budaya di dalam pesantren diadaptasi dengan kebutuhan masyarakat multi etnis dan agama.

\section{F. Referensi}

'Ali, Dzul Faqqar. Mu'jam al-Wasith . Kairo: ZIB, 1973.

'Âsyûr, Muhammad at-Thahir Ibnu. Tafsir At-Tahrîr wa al-Tanwir. Tunisia: Dar Shuhnun li al-Nasyr wa al-Tauzi', 1997.

A'l, Abdul Ghina A'bbud \& Hasan Ibrahim A'dul. at-Tarbiyah al-Islamiyah wa tahaddiyat al-Asyr. Mesir: Darul fiqr al-A'roby, 1990.

Ahmad Baso, et.al. K.H. Hasyim Asy'ari : Pengabdian seorang Kiai untuk Negeri. Jakarta: Museum Kebangkitan Nasional, 2017.

al-Asfahaniy, Al-Raghib. Mufradat al-Fadzul Qur'an. Beirut: Darel Qalam, 2009.

al-Ghazali, Abu Hamid. Ihya Ulumiddin, Jilid III. Beirut: Dar alFikr, t.th.

Al-Jazâ'iri, Jâbir. Aisar At-Tafâsîr li Kalâm al -'Aliy al-Kabîr. Jeddah: Racem Advertising, 1990.

al-Zuhaili, Wahbah. "al-Washathiyyah Mathlabun Syar'iyyah." In Pandangan Muslim Moderat, by Zuhairi Misrawi, 5. Jakarta: Kompas, 2010.

Bakri, Maskuri. Dekonstruksi; Jalan Terjal Membangun Negara Ketiga, Perspektif Pendidikan, Pemberdayaan dan Pelayanan Publik. Surabaya: Visi Press Media, 2017. 
-. Formulasi dan Implementasi Kebijakan Pendidikan Islam: Analisis Kritis terhadap Proses Pembelajaran. Surabaya: Visipres Media, 2017.

Banks, C. A. M. Banks \& J. A. "Equity Pedagogy: An Essential Component of Multicultural Education." Theory into Practice, 1995: 151-158.

Banks, James A. Multicultural Education: Goals and Dimension. Washington DC: University of Washington College of Education, 2011.

Bourdieu, Pierre. In Other Word. Cambridge: Polity Press, 1977.

Bourdieu, Pierrie. Distinction; A Social Critique of the Judgement of Taste. New York: Routledge, 2006.

-. Outline Of Theory of Practice. New York: Cambridge University Press, 1989.

Djauhari, Mohammad Tijani. Membangun Madura. Jakarta: Taj Publishing, 2008.

Felicia Tania K, et.al. "Studi Ikonografi Panofsky Pada Ornamen Interior Vihara Avalokitesvara Pamekasan, Madura." Jurnal Intra, 2017: 182-190.

Haris, Abd. Pendidikan Karakter Berbasis Tauhid; Sebuah Pendekatan Filosofis. Sidoarjo: Afkarpress, 2012.

Hasan, Mohammad Tholchah. Pendidikan Multikultural sebagai Opsi Penanggulangan Terorisme. Malang: Lembaga Penerbitan UNISMA, 2016.

Hilmy, Masdar. "Quo-Vadis Islam Moderat Indonesia." Jurnal Miqot, 2012.

Hilmy, Masdar. "Whither Indonesia's Islamic Moderatism? A Reexamination on the Moderate Vision of Muhammadiyah and NU." Journal of Indonesian Islam, 2013: 45.

Imam Suprayogo, et al. Merajut Benang Kusut: Studi Kasus Kerukunan Hidup Antarumat Beragama di Sitiarjo Kecamatan Sumbermanjing Wetan Kabupaten Malang. Malang: Laporan Penelitian Hibah Bersaing Dosen lain/Stain Sekolah Tinggi Agama Islam Negeri (STAIN) Malang, 001.

J., George Ritzer \& Douglas. Teori Sosiologi Dari Teori Sosiologi Klasik Sampai Perkembangan Terakhir, Teori Sosial Post Modern. Bantul: Kreasi Wacana, 2012.

Jeanne, Giacomo Corneo and Olivier. "A theory of Tolerance." Journal of Public Economics, 2009: 691702.

Jenkins, Richard. Membaca Pikiran Pierre Bourdieu, Penj. Nurhadi. Yogyakarta: Kreasi Wacana, 2010.

Jonge, Huub De. Garam, Kekerasan dan Aduan Sapi; Esai-esai tentang Orang Madura dan Kebudayaan Madura, Terj. Arief B. Prasetyo. Yogyakarta: LkiS, 2011.

Ketal, Felicia Tania. "Ikonografi Panofsky pada Ornament Interior Vihara Avalokitesvara Pamekasan Madura." Jurnal Intra, 2017.

Matuhu. Dinamika Sistem Pendidikan Pesantren. Jakarta: INIS, 1994.

Munif. Multikulturalisme dalam Pendidikan Madrasah; Nilai, Implikasi dan Model Pengembangan. Surabaya: Imtiyaz, 2016.

Nadzir, Mohammad. "Membangun Pemberdayaan Ekonomi di Pesantren." Economiuca, 2015: 48.

Richard Harker, Cheelen Mahar. (Habitus X Modal) + Ranah = Praktik. Yogyakarta: Jalasutra, 2005.

Soewarno, Nurtati. "Adaptation Of Architectural Style To Preserve Cultural Heritage Building; Case Study at Vihara Dewi Welas Asih-Cirebon." Journal of Architectural Research and Education (JARE), 2020. 
Mo'tasim, Maskuri Bakri, Djunaidi Mistar, M. Djunaidy Ghony, Nia Indah Purnamasari

Supandi. "Pembelajaran Aqidah Akhlak dalam Perspektif Humanisme di MA Miftahul Qulub Galis Pamekasan." Edureligia: Jurnal Pendidikan Agama Islam, 2019: 125.

Taher, Tarmizi. Aspiring for the Middle Path Islam: Religious Harmony in Indonesia. Jakarta: Center for the Study of Islam and Society IAIN Syarif Hidayatullah Jakarta, 1997.

Tilaar, H.A.R. Multikulturalisme: Tantangan-tantangan Global Masa Depan dalam Transformasi Pendidikan Nasional. Jakarta: Gramedia Widiasarana Indonesia, 2004.

Wiyata, Latief. Carok: Konflik Kekerasan dan Harga Diri Orang Madura. Yogyakarta: Lkis, 2002.

\section{Hasil Wawancara}

SWJ, Wawancara, Pamekasan, 1 Agustus 2019

MH, Wawancara, Pamekasan, 14 Februari 2019.

KS, Wawancara, Pamekasan, 14 Februari 2019.

RZK, Wawancara, Pamekasan, 17 September 2019.

MHD, Wawancara, Pamekasan, 15 Desember 2019

LKM, Wawancara, Pamekasan, 15 Desember 2019

ASN, Wawancara, Pamekasan, 7 April 2019

GYT, Wawancara, Pamekasan, 4 April 2019.

ASM, Wawancara, Pamekasan, 4 April 2019

LKN, Wawancara, Pamekasan, 16 Desember 2019. 